Erdey addressed the general assembly on the "Development of Polarography in Hungary".

The forty-six cornmunications that followed were divided into two parallel sections, one for applications in inorganic analysis, the other for biochemistry and biology. Lectures and discussions were in German, English, French, Hungarian and Slovak. General oscillographic polarography was discussed at a conjoint meeting by J. Heyrovský and quantitative oscillography by R. Kalvoda, who demonstrated their specially constructed cathode-ray oscillographs. As innovations may be mentioned: polarographic estimations of chromatograms (J. Proszt and J. Kis), automatic polarographic analysers of long duration (J. V. A. Novák), streaming of electrolytes induced by alteruating currents (J. Dévay), derivative currents obtained by electromagnetic induction ( $J$. Proszt and J. Paulik), deposition of magnesium at the streaming electrode (K. Györbiró, L. Poós and J. Proszt). In the biological section, several communications concerned Brdiǒka's protein test, the determinations of vitamins, oxygen in tissues, alkaloids and many applications in pharmacy and food production, and the study of macromolecules by means of suppression of maxima.

The communications will be published in full in German by the Hungarian Academy of Science in a special volume. Brief abstracts of the papers may be obtained through Dr. E. Bodor, Chemical University, Veszprém, Hungary.

It should be added that Veszprom lies close to the famous Lake Balaton, on the banks of which the delegates enjoyed discussions for several days after the Congress.

J. HEYrovskÝ

\section{NATIONAL PHYSICAL LABORATORY, TEDDINGTON REPORT FOR 1954}

$\mathrm{T}$ HE annual report for 1954 of the National Physical Laboratory, Teddington*, consists of the report of the Executive Committee which was presented to the General Board at its meeting during the afternoon of May 20, 1955, the annual open day of the Laboratory (see Nature, 175, 1102; 1955), and detailed reports, prepared by the respective superintendents, of the work of the nine divisions and Test House of the Laboratory.

The Executive Committee refers with particular pleasure to the visits of Their Majesties the King and Queen of Sweden on June 29, and of the members of the Royal Commission on the Civil Service on May 12. Other visitors during the year included parties from the Royal Naval College, Greenwich, and delegates from the joint spring meeting of the Institute of Metals with the Société Française de Metallurgie, and from the General Assembly of the Internationl Union of Pure and Applied Physics. A thirty-minute television outside-broadcast directly from the Laboratory took place on June 2, and the work of the Laboratory, with special reference to aerodynamics research, was also described in a schools' broadcast on October 27. In addition, the director of the Laboratory, Sir Edward Bullard, took the leading part in a studio programme, entitled "Power from the Sun", which was broadcast on October 11. - Department of Scientiffc and Industrial Research. National
Physical Laboratory: Report for the Year 1954. Pp. viii $+98+$ 7 plates. (London: H.M.S.O., 1955.) 48. net.
At the beginning of the annual report, the names of the members of the General Board, the Executive Committee, the Promotions Sub-Committee, the Froude Ship-Research Sub-Committee, and a newly constituted body, the N.P.L. Advisory Committee on Radioactive Standards, are listed. The new Committee formerly existed as an informal body, consisting of representatives of the Atomic Energy Research Establishment, the Radiotherapeutic Researeh Unit of the Medical Research Council, the Royal Cancer Hospital and the National Physical Laboratory; Dr. B. W. Robinson, superintendent of the Physics Division of the Laboratory, was appointed chairman of the Committee. In order to make the work of the Laboratory better known to industry, two liaison officers were appointed during the year for a three-year period, and it is reported that they have visited thirty-two research associations and have made direct contact with a number of industrial firms. The new building for the Metallurgy Division, which contains the refractories section, the $\mathrm{X}$-ray section and laboratories for work on radioactive tracers, was formally opened by Sir Lawrence Bragg on April 6, and in June a new Division, that of Control Mechanisms and Electronjes, was formed by amalgamating the control mechanisms section of the Metrology Division with the Electronics Division. The field of work to be covered by the new Division is a wide and important one, dealing with the automatic control of experimental, in. dustrial and administrative operations and the development techniques and equipment for dataprocessing and computation; but, at present, work is to be restricted to a continuation of that previously carried out by the two original sections.

The Laboratory took part in several exhibitions of scientific apparatus, including the Physical Society annual exhibition, the Royal Society soirées and a conversazione arranged by the Institution of Civil Engineers. Two international symposia were held during the year at the Laboratory, one in May on "Creep and Fracture of Metals at High Temperatures" and the other in November on "Precision Electrical Measurements". The proceedings of the symposium on "Automatic Digital Computers", held in March 1953, and four new booklets, Nos. 5-8, in the series "Notes on Applied Science" were published during the year. In addition, one hundred and fortysix scientific papers were contributed by members of the staff of the Laboratory to various journals and periodicals; lists of these are appended to each detailed divisional report.

The individual reports of the various divisions of the Laboratory indicate the wide range of scientific subjects covered. The Laboratory has, in addition to an extensive research programme, part of which is paid for by other government departments, certain specific responsibilities, including the maintenance of standards and routine test work. It would appear that the programme contains more items than are really desirable, and a reduction in the number in order to enable more rapid progress to be made with the remainder, and perhaps also to commence on a few new urgent items specially appropriate to the Laboratory, is being considered. The Aerodynamics Division has carried out important work on the application of boundary-layer control to the reduction of drag and the increase of lift. Helicopters appeared on the research programme of the Division for the first time, and a twin-rotor model for wind-tunnel tests was being made. Some fundamental work con- 
sisting of high-speed tunnel experiments on the flow of air at supersonic speeds over elliptic cones has already received practical application in the behaviour of high-speed aircraft and the use of highly swept wings.

In the Control Mechanisms and Electronics Division work has continued on digital computers, analogue computers and data-reduction devices. Two magnetic-drum stores have been installed on the pilot model of the automatic computing engine (ACE); an enlarged and improved version of the electronic simulator has been put into service and used in conjunction with the London School of Econornics for an extensive study of economic systems; and, at the request of the Committee on High-speed Computers of the Department of Scientific and Industrial Research, a group was formed in May to study the mechanization of large-scale clerical operations by means of electronic-digital techniques and equip. ment. A new impulse generator for $3.2 \mathrm{MV}$. was installed during the year in the high-voltage section of the Electricity Division, and, in connexion with its work on frequency standards, a highly stable oscillator controlled in frequency by a cavity resonator has been developed by the Division. Steady progress was maintained with the cresium atomic-beam standard.

The Light Division has spent several years developing methods for the production of diffraction gratings using techniques suggested by Sir Thomas Merton. The stage has now been reached where good-quality and reasonably sized gratings, suitable for use in research and industry, can be produced comparatively cheaply. Work on the application to the control of machine tools of the system of moiré fringes which is formed when two identical diffraction gratings are superimposed with their rulings nearly parallel has also been actively pursued. The Metrology Division reports considerable progress in the development of autocollimation and pneumatic gauging as a means of making highly accurate dimensional measurements for research and industry, and mention is made of the machines that have been built in the Laboratory to measure bore diameters of $0 \cdot 1-6$ in. to an accuracy of \pm 0.00001 in., in addition to an apparatus to measure the diameter of wire as fine as $0.0002 \mathrm{in}$. to a similar accuracy. A new absolute determination of gravity, in which the free up-down motion in vacuo will be timed, is envisaged, in order to improve the accuracy of measurement of barometric pressure and hence the steam point, and some preliminary work has already been done on the proposed interferometric method for measuring the distance over which the motion is to be observed. Consideration is also being given to the construction of a transportable primary-standard barometer for additional improvement of the precision of realization of the temperature $100^{\circ} \mathrm{C}$.

In the Metallurgy Division an investigation of the processes taking place during the fatigue of metals has been started, and in the study of intercrystalline fracture of ion alloys and certain copper alloys at low temperatures some remarkable results have been obtained. A comprehensive report was issued in Ortuber 1954 giving resultis of creep tests lasting up to ten thousand hours (more than a year) on steels to be used in the British Electricity Authority's new power stations. The Physics Division has co-operated in an international comparison of three resistance thermometers, constructed at the United States National Bureau of Standards, Washington, D.C., the Institute of Metrology, Leningrad, and the National Physical Laboratory, respectively, and its acoustics and sound measurement section has given assistance with a form of acoustical treatment designed by the Building Research Station for the stonework of the new Coventry Cathedral. The radiology section has constructed a new free-air ionization chamber for use with X-rays generated up to $300 \mathrm{keV}$. Features of the new chamber are that it is of the guarded-field type and that the air pressure and the potential of the case relative to that of the electrode system can be varied. The Mathematics Division has devoted most of its time to the solution of problems for industry and other government departments, using the pilot model of the automatic computing engine, and one of the largest problems tackled has been the analysis of stresses set up in the steam-catapult retardation structure in H.M.S. Ark Royal. An interesting development reported by the Ship Division is that tests were undertaken for the first time during the year on sailing yachts. Considerable assistance in other connexions has also been given by this Division to the Yacht Research Council.

Finally, the annual report, which is presented with an attractive cover and is illustrated, concludes with a report of the Test House and with a list of the senior staff of the Laboratory, arranged according to the various Divisions.

\section{EDUCATION IN ENGLAND AND WALES DURING 1954}

$\mathrm{T}$ $\mathrm{HE}$ report of the Ministry of Education on "Education in 1954"* gives statistics for primary and secondary education in England and Wales and for university awards and further education during the year; but the section on advanced technological education in technical colleges continues to display the confusion in which technological education still lies and which the institution of a new award recently announced by the Minister does nothing to remove. The number of children in the maintained schools increased by about 120,000 in 1954 and will continue to grow, but by decreasing amounts, until 1958. The number of children in the infant schools had already started to decline by the beginning of 1954; but the secondary schools will not receive their largest increase in numbers until 1958, and the peak will be reached at the end of 1960 . The provision of additional places in secondary schools is well in hand : of some 210,000 new places brought into use during the year ended October 1, 1954, 75,000 were in secondary schools, while a further 200,000 places were under construction; and the building programme for $1954-55$ is providing some 120,000 places in secondary schools out of a total of 187,000 .

The number of teachers increased by 6,100 in 1953 , and for 1954 the increase is estimated as more than seven thousand, while the entry of 11,768 students for two- or three-year courses at training colleges was the highest recorded. Generally, the staffing position tended to improve during the year ; by 1961 at latest, nearly all primary-school classes should be reduced to the regulation size of forty pupils or less, and in the secondary schools over the

- Education in 1954 : being the Report of the Ministry of Education and the Statistics of Public Education for England and Wales. Pp. viii + 197. (Cmd. 9521.) (London: H.M.S.O., 1955.) 78. 6d. net. 